\title{
Electricity portfolio innovation for energy security: the case of carbon constrained China
}

\author{
Konstantinos J. Chalvatzis ${ }^{1,2}$, Keagan Rubel ${ }^{3}$ \\ ${ }^{1}$ Norwich Business School, University of East Anglia, Norwich, NR4 7TJ, UK, \\ k.chalvatzis@uea.ac.uk \\ ${ }^{2}$ Tyndall Centre for Climate Change Research, University of East Anglia, Norwich, NR4 7TJ, UK \\ ${ }^{3}$ Keagan Rubel, Research Fellow, Mr. \& Mrs. S.H. Wong Center for the Study of Multinational \\ Corporations, 1922 Tice Valley Blvd., \#2460, Walnut Creek, CA 94595
}

\begin{abstract}
China's energy sector is under pressure to achieve secure and affordable supply and a clear decarbonisation path. We examine the longitudinal trajectory of the Chinese electricity supply security and model the near future supply security based on the $12^{\text {th }} 5$ year plan. Our deterministic approach combines Shannon-Wiener, Herfindahl-Hirschman and electricity import dependence indices for supply security appraisal. We find that electricity portfolio innovation allows China to provide secure energy supply despite increasing import dependence. It is argued that long-term aggressive deployment of renewable energy will unblock China's coal-biased technological lock-in and increase supply security in all fronts. However, reduced supply diversity in China during the 1990s will not recover until after 2020s due to the long-term coal lock-in that can threaten to hold China's back from realising its full potential.
\end{abstract}

\section{Keywords}

Energy security; China; climate change policy; diversification; electricity sector

\section{Introduction}

Access to energy is one of the most important aspects of modern and developed economies. Its importance extends wider than that of other commodities because without it they cannot be produced, delivered to the market, or used. Energy is used in all primary and secondary forms but during the last two decades the role of electricity has been rising [1]. This is not only a result of a proportional increase in energy consumption but also of a substitution of other energy carriers with electricity. For example this is taking place in buildings as electricity increasingly substitutes oil and gas for temperature control and cooking. It is also evident in rail and road transport with urban and intercity trains as well as private vehicles becoming electrically powered. Finally in industrial processes electricity substitutes steam driven processes $[2,3,4,5,6]$.

Electricity is a flexible form of energy for not only consumers but also producers. As a secondary energy carrier electricity can be generated with the use of primary fuels or renewable energy resources. Therefore producers do not have to rely solely on a certain fuel. 
When electricity is produced by renewable energy sources then it is the only form of energy with minimal environmental impact $[1,7,8]$.

Given the necessary role for energy and electricity in national security and economic development it is not a surprise that securing their supplies is implicitly or explicitly among the top priorities of every country. Following the definition for energy supply security by Grubb et al [9] it is essential to clarify that energy supply can be considered secure when its price does not disrupt the economy. At a national level, governments use a number of strategies to ensure supplies such as utilising indigenous resources, improving foreign relations with energy producing countries and facilitating efficient operation of energy markets $[10,11,12]$.

Diversity of production methods is a major strength for electricity supply security [13]. However, most of the energy security literature refers to primary energy resources and electricity tends to be under-represented in energy security research. A main reason for this is that electricity does not rely on a single resource for its production since it is produced in numerous ways; thus it requires a broader understanding of the energy context in order to encompass existing and alternative generation scenarios as they impact stability of supply and price dynamics. Furthermore, in contrast to most other commodities, electricity is not easily stored in a financially viable way. Therefore storage is a missing link in electricity's supply chain and this excludes solutions that would suggest buffering $[14,15,16]$.

On top of the difficulties that concern securing electricity supply, the electricity sector is a leading source of greenhouse gases (GHGs) in many developed and emerging economies. It also is the most concentrated sector in terms of emissions per source, and accounts for more emissions than any other sector $[17,18,19]$. At the same time potential reductions in the carbon intensity of the electricity sector can benefit other sectors, which can be partially electrified. For these reasons policies to reduce GHGs in most countries target primarily the electricity sector $[20,21]$. Reducing the carbon intensity of the electricity sector may include policies such as increased use of renewable energy sources and nuclear energy, substitution of coal with natural gas where possible, introduction of carbon capture and storage (CCS) technologies as well as efficiency improvements in existing power stations. Arguably, several of these substitutions, change the electricity sector's fuel mix and as a result contribute to changes in the electricity supply security [22,23].

China is currently managing the largest programme of low carbon technologies in the world [24]. This includes unprecedented investment in nuclear energy and renewables, particularly hydro and wind energy. This is not driven by socially adjusted incentives [25] but rather of a dash for electricity generation. At the same time, the Chinese government's 2012 Energy Policy [26] lists increased coal production amongst its top five key targets. This is not a surprise because the Chinese electricity sector relies heavily on coal. Until 2009 coal used for electricity came almost exclusively from indigenous resources in China. However, gradual ore depletion, increasing direct coal consumption and rapidly growing electricity demand led China to become the world's largest coal importer soon after it started importing [27]. In 
parallel, the supply of nuclear fuel to China relies heavily on imports; it is forecast that by $2020,2 / 3^{\text {rd }}$ of uranium sources will be imported, roughly half of all non-indigenous sources coming from foreign imports and half from Chinese overseas possessions [28,29]. The forecast increased energy demand (particularly fossil fuels) is one of the main reasons for which China has not subscribed to international agreements to control emissions of greenhouse gases.

With regards to nuclear power China is leading the world in the second phase of what is often called the "nuclear renaissance" [30], referring to the post Chernobyl and Three Mile Island rapid development of nuclear energy that takes place mainly in Asia. The IAEA suggests that $72 \%$ of the reactors currently under construction are found in five countries China (29 including 2 at Taiwan); India (6); South Korea (5); Pakistan (2); and Russia (10) [31]. However, recent studies cast doubt on the uranium supply over the forthcoming decades [29,32].

The role of status quo bias and decision making in the energy sector has been explored from a number of different angles. With a focus on strategic decision making and planning of energy investment, Wüstenhagen et al [33] suggested that the industry has to overcome its status quo bias and pathway dependency in order to contribute to renewable energy development. Pahle [34] found that the last decade's "dash for coal" in Germany has partly been a result of status quo bias among the power market investors who did not take into account the governmental plans for further renewable energy investment. Goldthau and Sovacool [35] took this argument one step further to say that pathway dependency is a defining characteristic of energy policy and one that makes it distinct among other international policy areas. Pathway dependency is linked to lack of resilience in the energy sector. Strong pathway dependency reduces the ability to adopt abrupt changes, thus threatening the resilience of energy systems and energy supply security. One more link to energy supply security and pathway dependency was made by Vleuten and Lagendijk [36], who examined the European power blackout of 2006 [37]. They found electricity policy pathway dependencies to be one of the parameters determining which countries were affected by the event.

The aim of this paper is to examine the status quo and potential future of electricity supply security in China. Even though China has a rapidly developing economy, the legacy of its electricity sector is taken into consideration in order to discuss potential pathway dependencies. Furthermore, the forthcoming Chinese climate and energy policies are reviewed to inform possible fuel mix futures and their respective impact on emissions and electricity supply security.

This manuscript continues with a brief description of the case study i.e. the Chinese electricity sector and its specific challenges. Following that, in the third section we describe the methodological approaches used for assessing electricity supply security. In this section there is explicit reference to the data that was used for this study. The fourth section presents and discusses our results and finally the paper concludes with the implications beyond China's borders of electricity security in China. 


\section{Electricity sector of China}

\subsection{Status quo}

China's electricity sector is the largest in the world, and electricity consumption in the country reached 5,322 TWh in 2013 [38], with demand expected to rise to 9,845 TWh by 2030 [39] (Figure 1). China is the world's largest consumer of coal and its electricity sector is the largest single source of coal demand consuming approximately half of the country's coal [40].

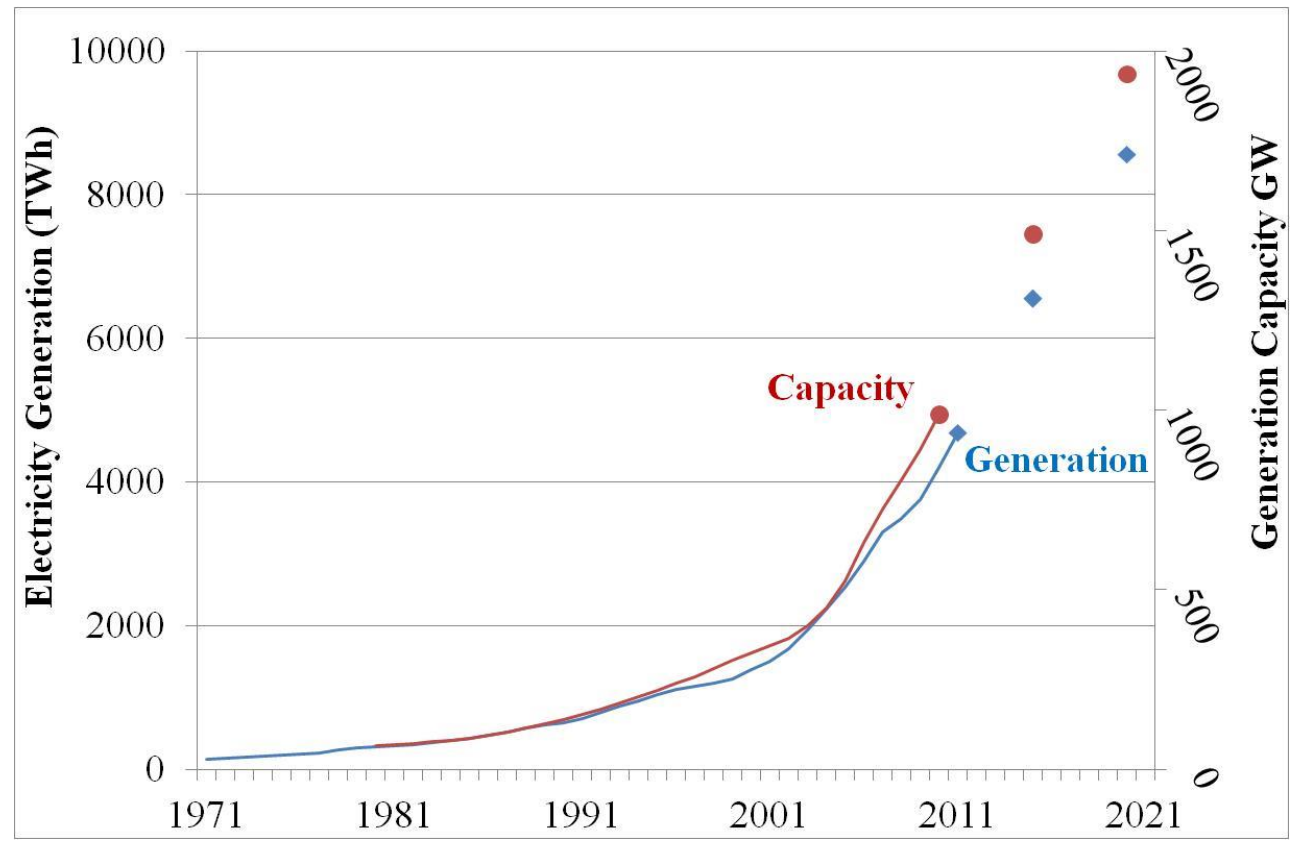

Figure 1: Past and projected electricity generation and electricity generation capacity in China

Increased concern about global warming from anthropogenic emissions has put major greenhouse gas (GHG) emitters under scrutiny by the international community. China's rapid development since its partial economic liberalization in 1978 has come at great environmental expense [41] and resulted in annual GHG emissions of 7,222 $\mathrm{GtCO}_{2} \mathrm{e}$ in 2010 making it the world's leading emitter. China's electricity sector specifically has become a focal point, both because of its strain on global natural resource supplies and emission-intense nature. Internationally the electricity sector accounts for $42 \%$ of annual $\mathrm{GHG}$ emissions from fossil fuels; nationally, China's electricity sector accounts for over half of its total emissions [42].

In addition to reducing carbon emissions, China urgently needs to combat air pollution. So far, this issue has been approached mostly on a regional and urban basis but as the European and North American experience suggests the most dangerous pollutants are easily transferred across borders [43]. Synergies between air pollution and carbon reduction are straight- 
forward in all the decarbonisation options, particularly those suggesting focusing on renewable energy sources and nuclear.

Prior to economic liberalization in 1978, China's electricity sector was operated by the Vertically Integrated State Owned Utility (VISOU), which has undergone significant transformations and is now privatized and dismantled [44]. The resulting competition increased the generation capacity that was needed to satisfy China's growing demand, which comes primarily from the industrial sector; from 1980 to 2009, electricity demand grew 12fold and is projected to continue [45, 46]. Energy security concerns dictate that China meet its electricity needs with domestic resources, resulting in a system heavily reliant on coal. Recent developments and national policy demonstrate China's will to diversify its primary fuel mix in electricity generation. However, exploitation of coal resources is the top national energy priority [47].

Approximately $75 \%$ of China's electricity demand comes from industrial base-load facilities, causing a relatively flat demand profile. This flat profile is conducive to China's predominately inflexible base-load generation, however leads to integration problems for intermittent resources. China's inflexible system may be increasingly inappropriate as the electricity demand profile becomes more volatile with anticipated increases in residential and commercial demand.

Geographical diversity of resource location and demand centers is a major problem for China's power sector, as coal is predominately found in the North and demand centers are located largely in the East. Some non-coal power sources face the same problem. For example, hydropower is located predominately in the South, while wind resources are mostly located in the North and Northeast. In the case of wind power, this causes frequent curtailment and also non-connected installed capacity rates of up to $25 \%$ in areas such as East Inner Mongolia that have received the bulk of China's wind capacity buildup [48].

While renewable energy plays only a small role in China's electricity generation, it is worth noting that various legislations have been passed to encourage it. Notably, The Renewable Energy Law (REL) in 2005 requires non-hydro renewable power generation to account for 3\% of the electricity generation by 2020 . This has succeeded in stimulating certain technologies; wind capacity grew from $0.3 \mathrm{GW}$ in 2000 to $25.8 \mathrm{GW}$ in 2010 [49]. Also, China's $12^{\text {th }} 5$ Year Plan, discussed further below, suggests aggressive clean energy targets, including to increase the share of non-fossil fuel consumption of primary energy to $11.4 \%$ [50].

China's electricity consumption continues to grow rapidly, reaching a growth rate of $7.2 \%$ in the first three quarters of 2013, while electricity production for the same period grew at $6.8 \%$ [51]. Given the dominate position of coal in the electricity production fuel mix (79\% in 2011) it is natural that coal consumption will remain the major way that China will meet growth in electricity demand for the foreseeable future.

\subsection{China's Historic Electricity Fuel Mix Development}


China's coal endowments are some of the largest in the world [52]. This abundant and cheap fuel supply facilitated China's heavy industry development, which required continuous electricity supply and therefore coupled well with the base-load features of coal-fired power systems. Coal thus became deeply embedded in China's $20^{\text {th }}$ century energy system. Between 1971 and 2011 (figures 2-6), coal-fired generation accounted for between 49\% (1976) and 80\% (2007) of total generation [53, 54].

Coal's moderate contribution to generation in the 1970's and subsequent increase in relative importance in the electricity sector generation correlates with the development of China's oil fields, which began to undergo commercial development in the 1960's. By 1971, oil contributed $11 \%$ to total electricity generation and peaked in 1976 at $29 \%$ of total production. However, over the following two decades of economic liberalization and growth in vehicular demand, oil use in electricity generation declined steadily and by 2011 accounted for only $0.3 \%$.

Hydropower's significant role in China's power generation portfolio has stayed relatively constant, accounting for between 24\% (1974) and 15\% (2003) throughout the period 1971 to 2011. Government targets to increase the installed capacity of China's hydro power to 300 GW by 2020 (from $219 \mathrm{GW}$ in 2010) (figure 7) ensure that hydro will continue to make an important contribution to China electricity portfolio mix into the mid-term future.

China's nuclear power sector was launched in 1993, and has scaled by 2014 to have 21 plants in operation with 28 more under construction. China aims to generate $6 \%$ of its total electricity with nuclear power by 2020, up from $1.84 \%$ in 2011 [55].

Natural gas was exported from China until 2007, and by 2012, imports met 29\% China's natural gas demand and is expected to grow. Natural gas plays a small but growing role in China's power sector. With the first natural gas-powered generation coming online in 1980, its role in electricity generation has grown steadily to account for over $2 \%$ of China's total electricity generation portfolio by 2011. China is increasing the role that gas will play in its energy mix by increasing production and by building the infrastructure needed to boost imports via pipeline and liquefied natural gas. However, the growth in the use of natural gas in power generation is not expected to maintain pace with the growth of electricity demand, and by 2020 official estimates predict that natural gas's use in electricity generation will dip to $1.85 \%$ of total supply [56].

Non-hydro renewable energy sources in China historically have not played a significant role in China's fuel mix, but there is an attempt to ease the pressure on its coal-based generation by developing renewable electricity sources. Notably, China's wind power has undergone rapid growth since 2006 when China published its Renewable Energy Law, which stimulated renewable electricity generation. By 2011, China generated 70,333 GWh of wind power, compared to 2,028 GWh in 2005 - an average annual growth rate of $75 \%$ during that period. Photovoltaic power has also experienced rapid growth, but is predicted to play a much less significant role in China's overall generation mix. Biomass, geothermal, tidal and other forms 
of renewable energy have not historically been significant sources of electricity, nor are they predicted to account for any substantial generation in China's short and mid-term energy future. By 2011, photovoltaic electricity has produced 2,532 GWh. Biomass and geothermal generation similarly made only small contributions to China's overall generation portfolio.

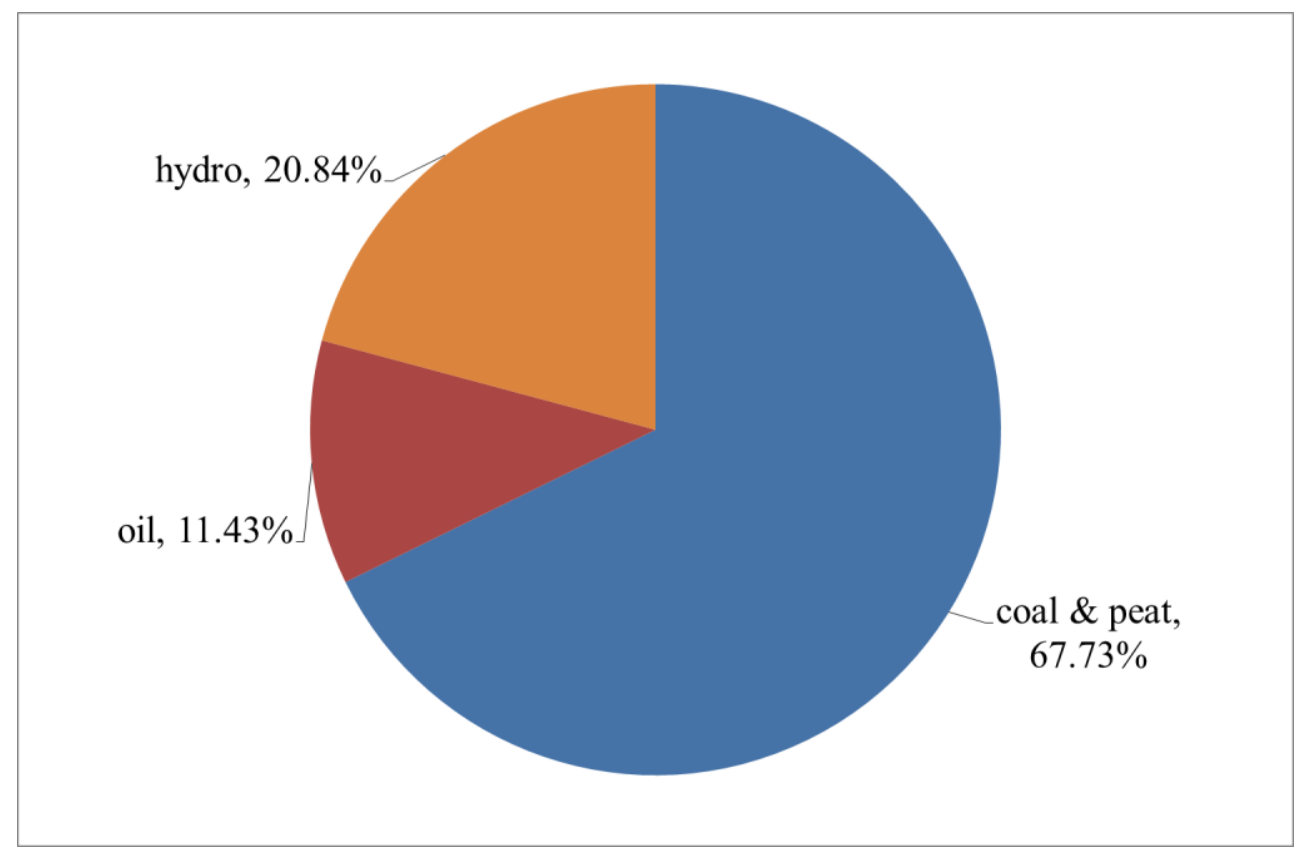

Figure 2: Chinese electricity sector's fuel mix in 1971

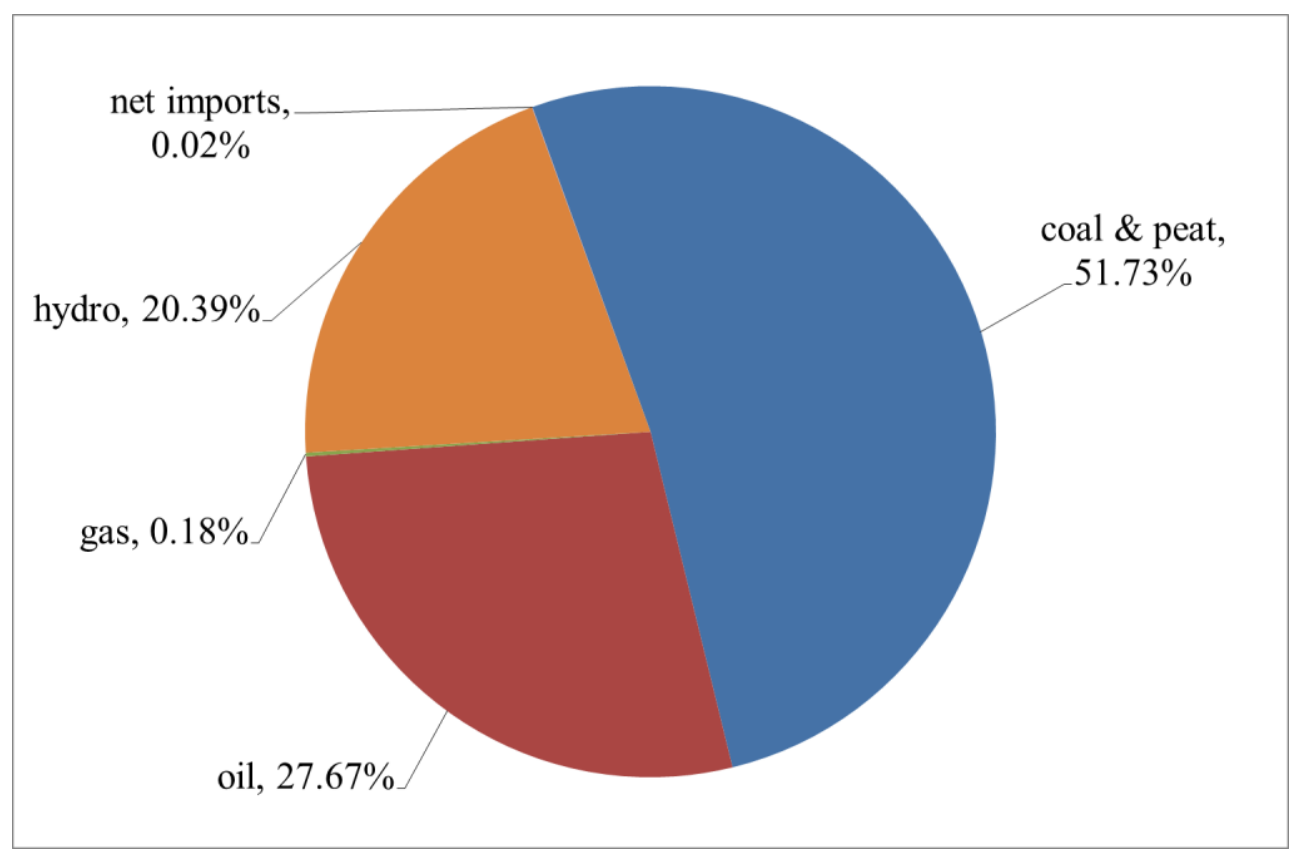

Figure 3: Chinese electricity sector's fuel mix in 1981 


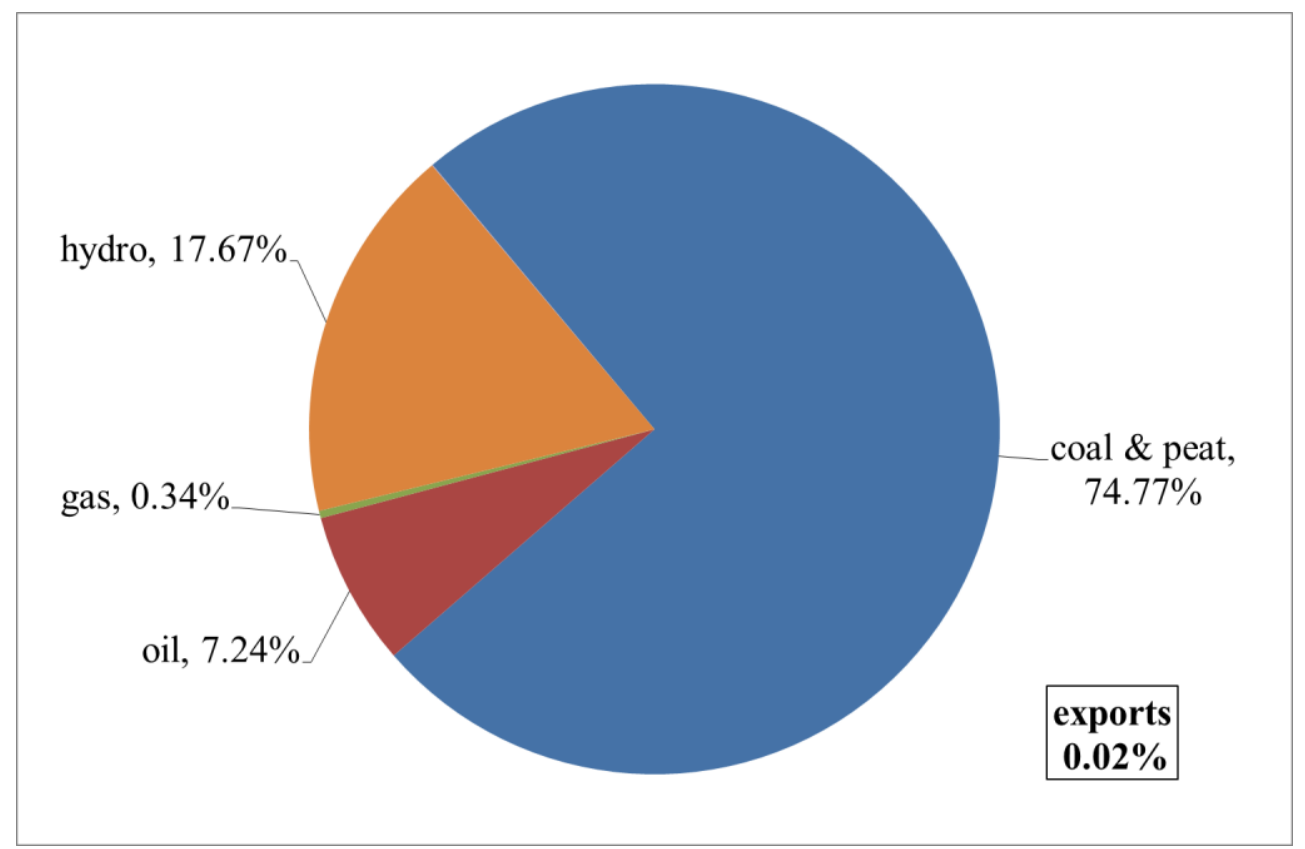

Figure 4: Chinese electricity sector's fuel mix in 1991

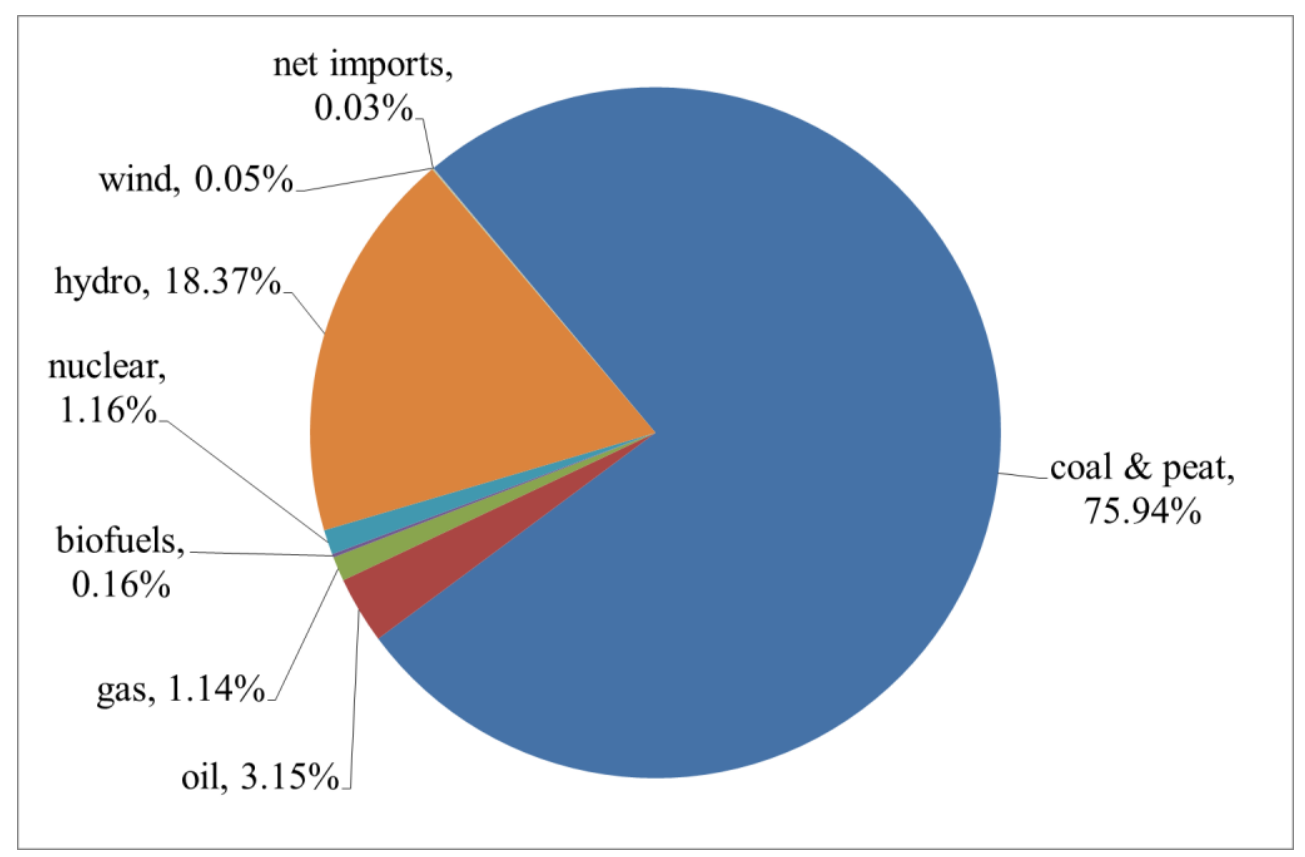

Figure 5: Chinese electricity sector's fuel mix in 2001 


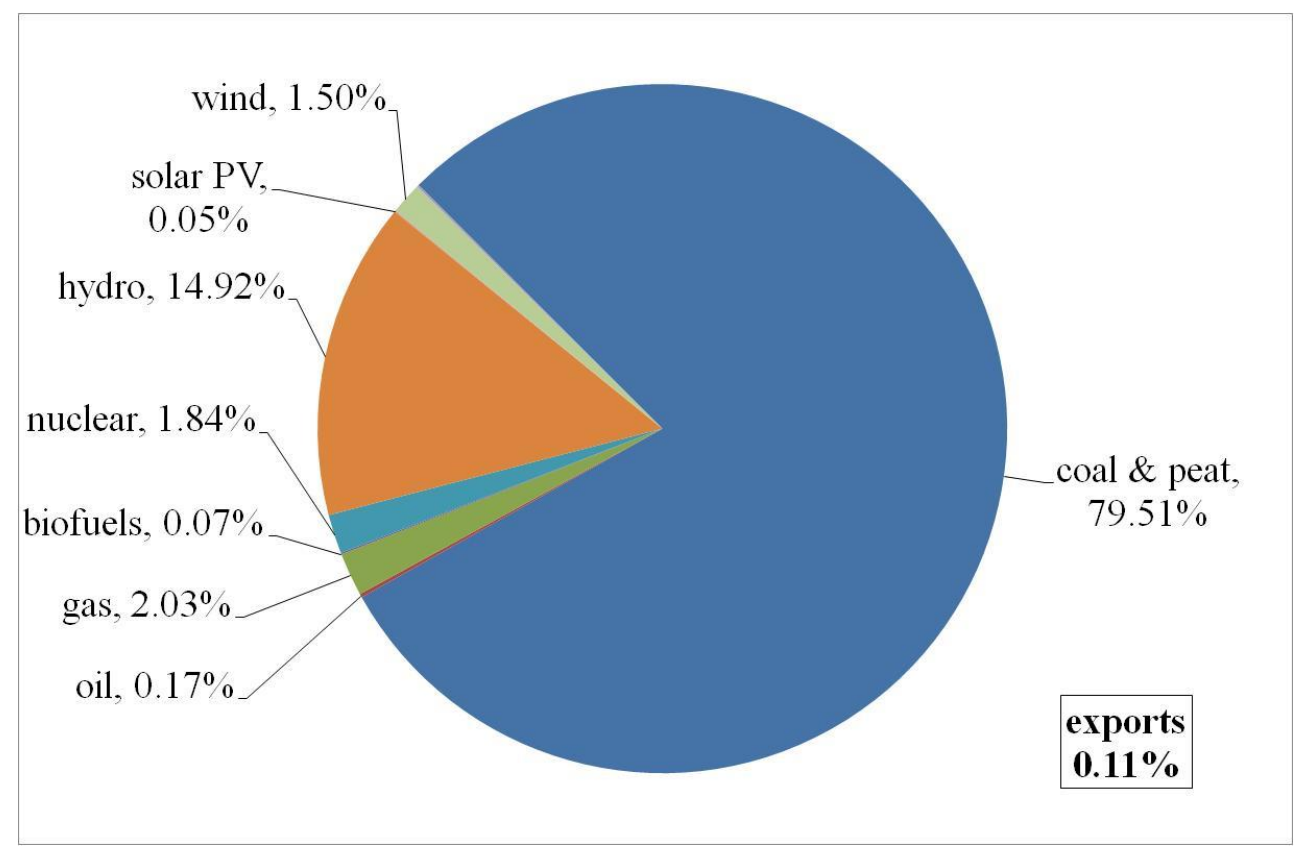

Figure 6: Chinese electricity sector's fuel mix in 2011

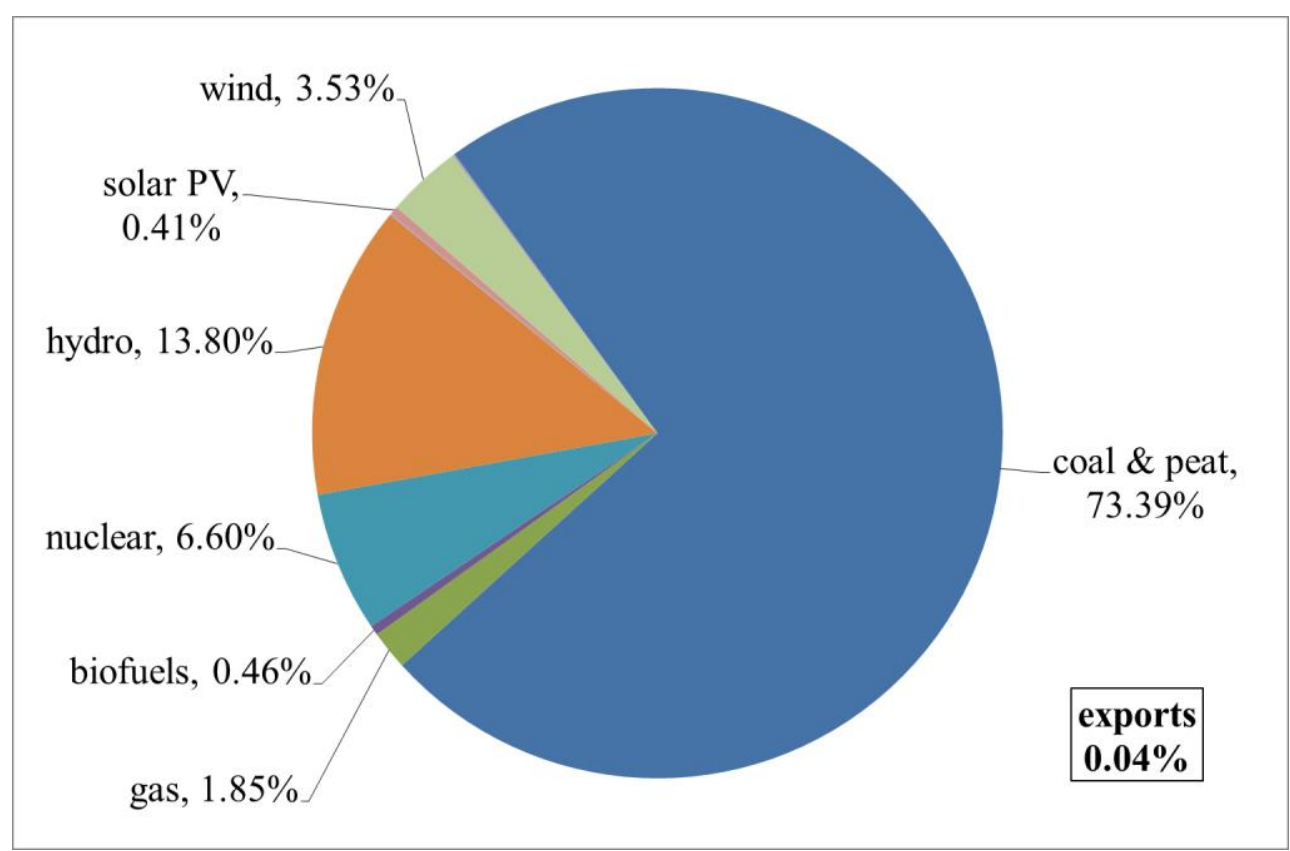

Figure 7: Projected Chinese electricity sector's fuel mix in 2020

\subsection{China's Coal Consumption \& Production}

Growth in China's coal consumption is closely linked to growth in electricity generation. $79 \%$ of its electricity was generated from coal in 2011 [53], and electricity production accounted for $49 \%$ of total coal consumption [54]. Growth in demand remains one of China's largest obstacles in curbing its consumption of coal; average growth of electricity generation between 2002 and 2011 was 12.2\% [53]. China's State Grid Economic Research Institute (SGERI) projects high and low demand scenarios for the electricity sector in 2020 of 8,510 TWh and 6,947 TWh respectively [39]. Non-coal energy targets are already aggressive. Growth in installed capacity of non-coal electricity generation is expected to rise from the 
$224 \mathrm{GW}$ in 2009 to $586 \mathrm{GW}$ in 2020, with the resulting 2,200 TWh of estimated output signifying an upper limit of what would be technically feasible in that timeframe [57]. Therefore, the differences in SERGI's demand scenarios would include between 6,310 TWh and 4,747 TWh of predominantly coal-based sources from a 2009 baseline of 3,557 TWh coal generated electricity. This implies a large growth potential of coal consumption from China's electricity sector, the extent of which is largely dependent on China's ability to manage growth in its electricity demand.

Given its large domestic coal endowments, China's coal production has historically far exceeded its consumption. Looking specifically at coal used in electricity production, net bituminous coal exports peaked in 2001 at $68.6 \mathrm{Mt}$. China's production of bituminous coal has grown rapidly in recent years, rising from 1.21 billion tons in 2000 to 2.77 billion tons in 2011, with an average growth rate of 7.64\% [53]. However, during that same period, China's demand for coal grew even faster, and surpassed local supply; consumption of bituminous coal rose from 1.26 billion tons in 2000 to 2.93 billion tons in 2011 - an average growth rate of $7.80 \%$ for the same period. While bituminous coal imports only accounted for $0.61 \%$ of total steam coal consumption in 2000, by 2011 imports accounted for $3.87 \%$, a six-fold increase in reliance on bituminous coal imports for electricity generation [53]. This supply and demand imbalance has been mirrored in other coal consumption sectors, and shifted China's position as a significant coal exporter to the world's number one importer in 2009; in that year China's imported $126 \mathrm{Mt}$ of net coal, which accounted for $15 \%$ of global coal trade, and accounted for $13.97 \%$ of its overall coal consumption. By 2011, China imported 196 million tons of coal, accounting for just over $17 \%$ of global coal trade [53].

China's dependence on coal imports is projected to continue, in part due to a national goal to limit coal production capacity to 4.1 billion tons during the Chinese $12^{\text {th }} 5$ Year Plan period of 2011-2015, according to government news sources [50]. Problems resulting from production and use of coal resources are well documented and the central government policies help to mitigate issues such as preserving indigenous supplies, limiting the strain on existing coal transportation infrastructure, and reigning-in environmental damage caused by coal mining [58]. China's coal industry development plan for the 2011-2015 dictates that coal production not exceed at 3.9 billion tons annually, potentially contributing to increased reliance on imports [59].

Compounding China's increasing reliance on coal imports is the trend towards electrification. The IEA estimates that electricity accounted for $6 \%$ of China's final energy consumption in 1990, and by 2007 had grown to $19 \%$. IEA forecasts this figure to rise to $27 \%$ by 2020 as an increasing share of the energy it consumes comes in the form of electricity [60].

China's recent reliance on coal imports marks a turning point in China's energy security, and more specifically its electricity security. Most research on China's energy security focuses on the substantial gap between oil production and consumption. Indeed, China's national energy strategy historically has been to rely on domestic resources, which until recently it has successfully done for all major energy sources other than oil $[61,62,63]$. However, a 
predominant focus on oil overlooks the recent, and growing, production/consumption imbalance of coal, which plays a much larger role in China's overall energy portfolio. The implications for China's electricity security and of its existing and future fuel mix scenarios have not been sufficiently explored by existing literature.

\section{Methodology}

Until recently researchers focused on defining energy security [64] and establishing theoretical or qualitative frameworks to conduct energy security analyses $[65,66]$. Energy policy studies are increasingly incorporating quantitative indicators serving as proxies for measurements of energy security $[67,68,69,70]$. The two most distinct quantitative approaches for energy supply security use measures of diversity or measures of energy dependence, both of which will be reviewed here. Other energy security indicators comprise of a combination of dependence, diversity, other macroeconomic indicators and stochastic approaches $[71,72]$.

The adopted approach is straight-forward and novel. It is straight-forward because we use the most established concepts to assess supply security; dependence and diversity. Both are estimated with straight-forward indices that were used before in the energy security literature. The novelty of our approach is that never before was the combination of these indices used to analyse the long-term past and mid-term future electricity supply security status of China. In the following sections the details of the quantified measures of dependence (3.1) and diversity (3.2) are provided. The data used is mainly available through International Energy Agency (IEA).

\subsection{Electricity supply dependence}

The concept of energy dependence may seem obvious with regards to reliance on primary fuels. However, further analysis by Frondel and Schmidt [73] resulted in an indicator assessing the specific risks associated with each primary fuel, taking into account information about the worldwide supply of that fuel and its importance for the country in question. Chalvatzis and Hooper [74] and Chalvatzis [22] provided a clear focus on electricity supply security. The authors suggested a new index that takes into account the direct electricity imports and imports of primary energy resources that are used to generate electricity. Hence:

$$
\text { Dependence } D=D_{e}+D_{f}(1)
$$

Where:

$D=(\%)$ electricity supply dependence

$D e=(\%)$ dependence on direct electricity imports

$D f=(\%)$ dependence on primary fuel imports for electricity generation

\section{$\underline{3.2 \text { Electricity supply diversity }}$}

There are several quantitative approaches on energy diversity. Cohen et al [75] proposed global and country-specific diversification indices for oil and gas supplies. Le Coq and 
Paltseva [76] used energy import diversification, combined with measures of political risk, risks in energy transit and economic costs of supply disruption to define indices evaluating the risks of disrupting oil, gas and coal supplies in Europe. These quantitative measures of energy diversity generally focus on the use of Shannon-Wiener $[9,13,77,78]$ and HerfindahlHirschman indices $[9,75,79,80]$.

\subsubsection{Shannon Wiener Index}

The Shannon-Wiener index was originally used in the disciplines of ecology and genetics in order to describe diversity in species populations and specific genomes. Stirling [13] introduced it first to energy supply diversity. According to Grubb et al [9], when the Shannon-Wiener index is below 1 it indicates a significant lack of diversity, whilst an index higher than 2 indicates a diverse fuel mix which means there is no overreliance on certain options. However, Hickey et al [77] acknowledge that one difficulty of using the ShannonWiener index in energy diversity appraisal is that there is no "explicit range of values that would indicate excessive or insufficient fuel diversity". For $n$ number of fuels (options) available in the electricity fuel mix the Shannon-Wiener Index (SWI) is:

$$
S W I=-\sum_{i=1}^{n} S_{i} \cdot \ln S_{i}
$$

Where:

$S i=$ the share of fuel (option) $i$ in total available electricity

For the calculation of the SWI each fuel available in the electricity fuel mix represents one option. Each option's share is expressed as a segment lower than one i.e. a share of $20 \%$ would be used in the calculations as 0.2 . The SWI is minimised to zero when only one option is available and can be maximised with infinite options.

\subsubsection{Herfindahl-Hirschman Index}

The Herfindahl-Hirschman Index (HHI) is used widely in competition economics to measure market concentration, which is the opposite of diversity. It is also known as the Simpson Index in ecology. Unlike SWI, HHI is a measure of concentration rather than a measure of diversity. Therefore the higher the HHI, the higher the concentration; thus the lower the diversity. The HHI index is calculated as the aggregate of the squared share of each option.

$$
H H I=\sum_{i=1}^{n} S_{i}^{2}
$$

Where:

$S i=$ the proportion of option $i$ expressed as a percentage

Similar to the calculation of SWI, each fuel represents an option for HHI. The options' shares are expressed as percentages i.e. a share of $20 \%$ would be used in the calculations as 20 . The US Department of Justice [81] suggests that HHI lower than 1,500 indicates a competitive 
marketplace and higher than 2,500 indicates a highly concentrated marketplace. Following this guidance Grubb et al [9] suggest that these values can be used to assess energy supply diversity.

\section{Results and discussion}

\subsection{Electricity supply dependence}

Following the process described in section 3 we calculate the long-term import dependence of the Chinese electricity sector (Figure 8). China has been a net importer of oil and gas since the 1990s. However, these fuels played only a small role in electricity generation between 1990 and 2011. In contrast, solid fuels were produced in China and their production consistently followed domestic demand; therefore it can be said that until 2008, China produced nearly all the fuels it required to generate power. Dependence on oil and gas imports increased rapidly since the 1990 s reaching $78 \%$ and $34 \%$ respectively in 2011 . The electricity sector's total dependence was consistently below 1\% until 2008 and reached 6\% in 2011. This sudden dependence growth can be attributed by nearly $59 \%$ to coal imports reaching $4.5 \%$ in 2011 . In comparison approximately $11 \%$ is attributed to natural gas, $27 \%$ to nuclear and $2 \%$ to oil imports. In the near future, by 2020 the import dependence of the Chinese electricity sector is predicted to reach an unprecedented $32 \%$.

For several countries nuclear energy is considered to be a predominantly indigenous source. However, for China nuclear energy is heavily relying on uranium imports. China imported 16,126 tons of uranium in 2011, not much less than the 17,135 tons it had imported in 2010, according to the General Administration of Customs [82]. The National Energy Administration predicts that imports will remain the same or be increased during 2012 and the World Nuclear Association predicts that they will reach 20,000 tons by 2020 [83]. Approximately $95 \%$ of uranium imports to China are coming from Kazakhstan, Uzbekistan, Namibia and Australia while China produced about 1000 tons in 2012. However, it is reported that China consumes less than 7,500 tons of natural uranium annually leading to conclusions that large amounts of imported uranium are used for stockpiling [84]. In addition to securing increased uranium imports, China needs to accelerate the development of uranium processing plants that will allow it to produce nuclear fuel rods [85]. 


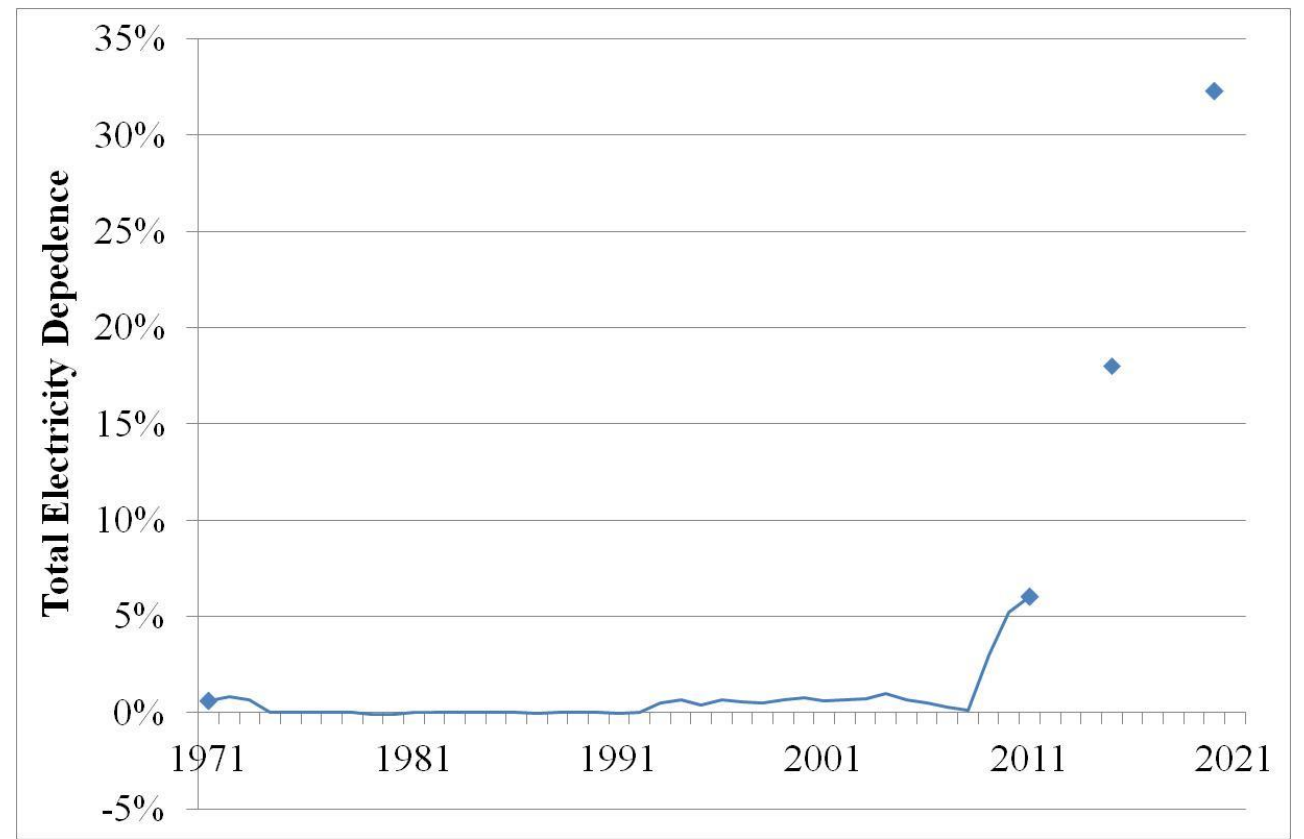

Figure 8: Past and projected electricity supply dependence in China

As it has been demonstrated all thermal power generation increases the import dependence of the Chinese electricity sector since it relies to some extend on imported fuels. Only renewable energy sources can potentially reduce electricity import dependence. By 2020 the official planning of the Chinese Government predicts a fuel mix that will have an increased role for wind energy, solar PV and bio-fuels by $2.03 \%, 0.36 \%$ and $0.39 \%$ (since 2011 ) respectively (Figure 7). However, this increased role for renewable energy sources will be shadowed by a reduction of $1.12 \%$ in hydropower which will results in a total $1.66 \%$ total increase of renewable energy sources. Clearly this is not adequate to control the impact of nuclear and coal energy on dependence.

Specifically, as it has been discussed in section 2 China is bound by its own policies to increase coal imports rapidly since it will restrict indigenous coal production; therefore even though reliance on coal is reduced by $6.13 \%$ as a percentage of the total generation fuel portfolio between 2011-2020 coal import dependence will increase from 4.45\% in 2011 to $37 \%$ during the same period as the total consumed amount increases. At the same time the contribution of nuclear energy will increase significantly from $1.84 \%$ to $6.6 \%$. 


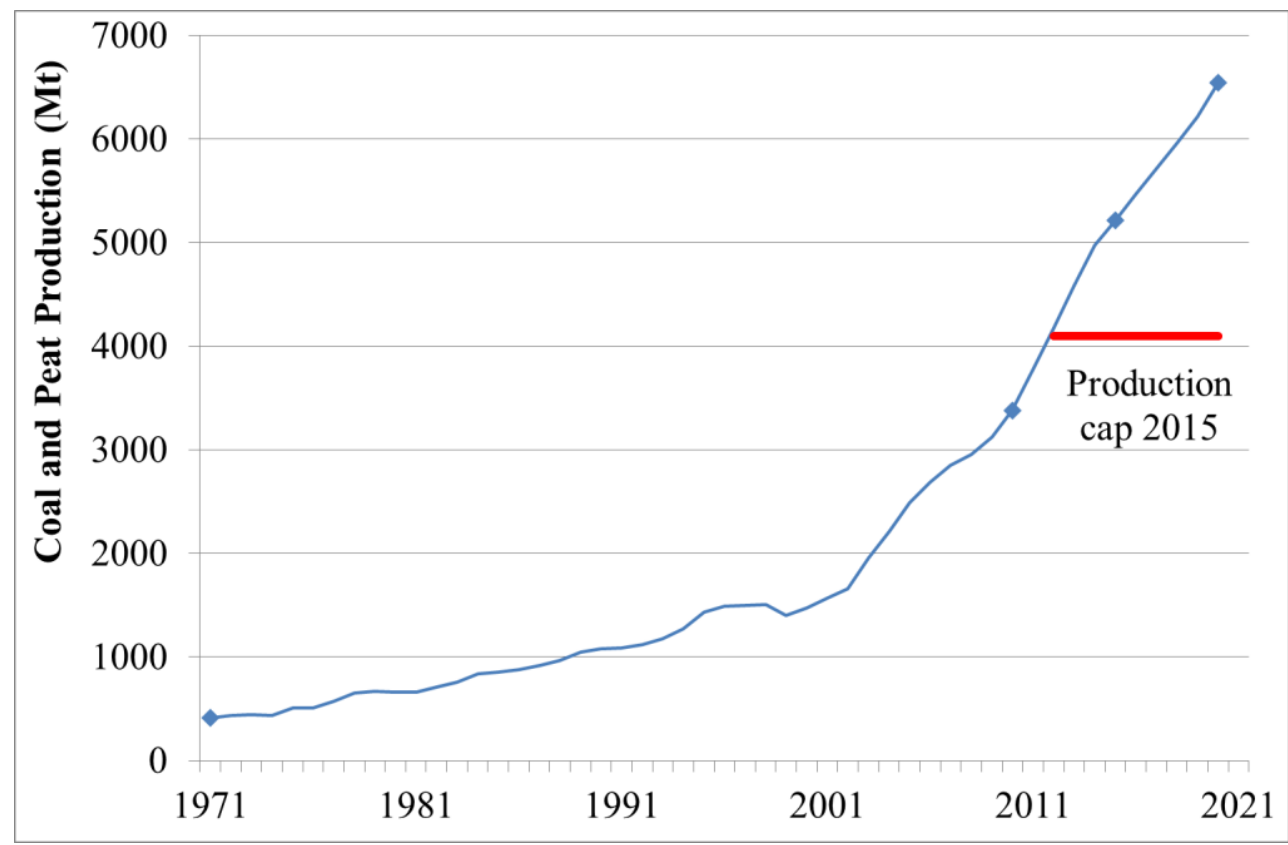

Figure 9: Past and projected coal and peat production in China with production cap

\section{$\underline{4.2 \text { Electricity supply diversity }}$}

Import dependence is only one aspect of energy supply security. For a country like China that has enormous energy needs, diversity of energy resources is at least equally important. Due to lack of appropriate data we are not examining import diversity i.e. the diversity of countries, regions and sources that China imports its energy resources from. In fact it is often commented that China has adopted a long-term strategic approach on this issue including foreign acquisitions and stockpiling of energy resources [86, 87, 88]. Diversity is examined here in the context of the different resources used for electricity generation. Our approach is based on the actual contribution of each resource to the available electricity rather than on the installed capacity of different technologies. As mentioned in section 3 we have used two complimentary indices HHI (figure 10) and SWI (figure 11).

Both indices are very sensitive to the total number of options used in the fuel mix; therefore they tend to show disproportionately large diversity increase even when an option with negligible contribution is introduced to the fuel mix [22]. To enhance the robustness of our approach against this over-sensitivity we estimate the respective indices 3 times; one that includes all options (even those with negligible contribution); one that includes all options with a contribution higher than $1 \%$ and one that only includes options with a contribution higher than 3\%. It is clear that SWI is more sensitive than HHI to options with negligible contribution as it occurs from the significant difference between the 3 curves (figure 11). It is noteworthy that the number of fuel mix options that are taken into account in these calculations varies throughout the examined period (1971-2020) between 3 and 8 when accounting for all options, 3 and 5 when only accounting for options with a contribution higher than $1 \%$ and 2 and 3 when only accounting for options with a contribution higher than $3 \%$. The number of options considered follows an increasing trend when all options are considered (from 3 to 8) and a similar increasing trend when only options with a larger than 
$1 \%$ contribution are considered (from 3 to 5). Conversely, the number of options follows a decreasing trend (from 3 to 2 ) when only options with a larger than $3 \%$ contribution are considered.

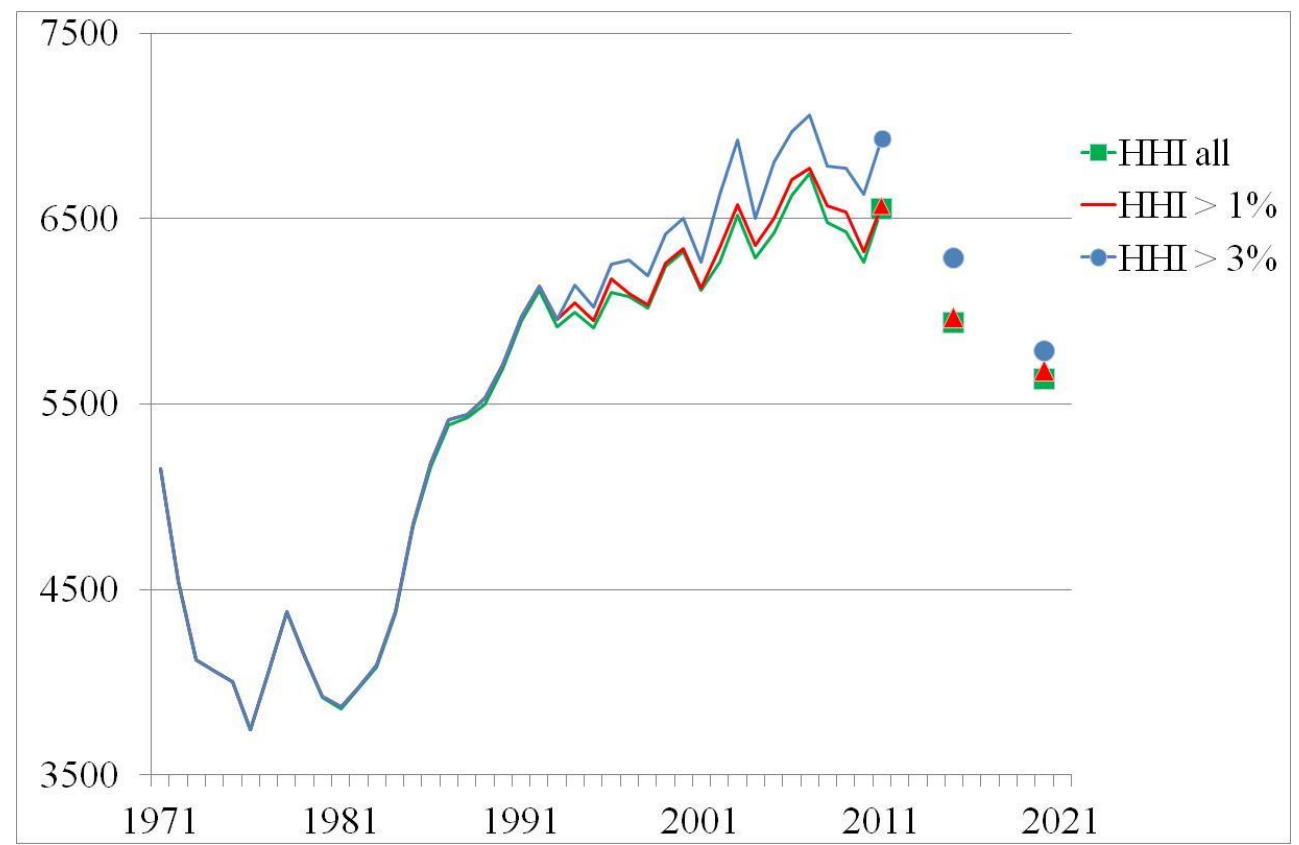

Figure 10: Past and projected HHI

Despite the aforementioned sensitivity differences both indices show similar trends. It is reminded that $\mathrm{HHI}$ is a measure of concentration which is opposite to diversity and for this reason the two indices appear to mirror each other. The diversity of the Chinese electricity sector was increased between 1970 and 1980 as a result of the large role of oil and natural gas in the fuel mix (Figures 2 and 3). Following the 1980s diversity followed a downwards trend for 3 decades reflecting the dominance of solid fuels in the electricity sector's fuel mix. As the contribution of non-coal energy resources in the fuel mix is predicted to increase the diversity is expected to improve significantly. Specifically, resources like nuclear, bio-fuels, wind and solar PV are projected to increase their share between 2011 and 2020 and make a positive contribution to diversity. However, it is important to notice that despite the projections for diversity improvement, diversity will not reach its 1970's level until after 2020 even if all fuel mix options are taken into consideration in its estimation. 


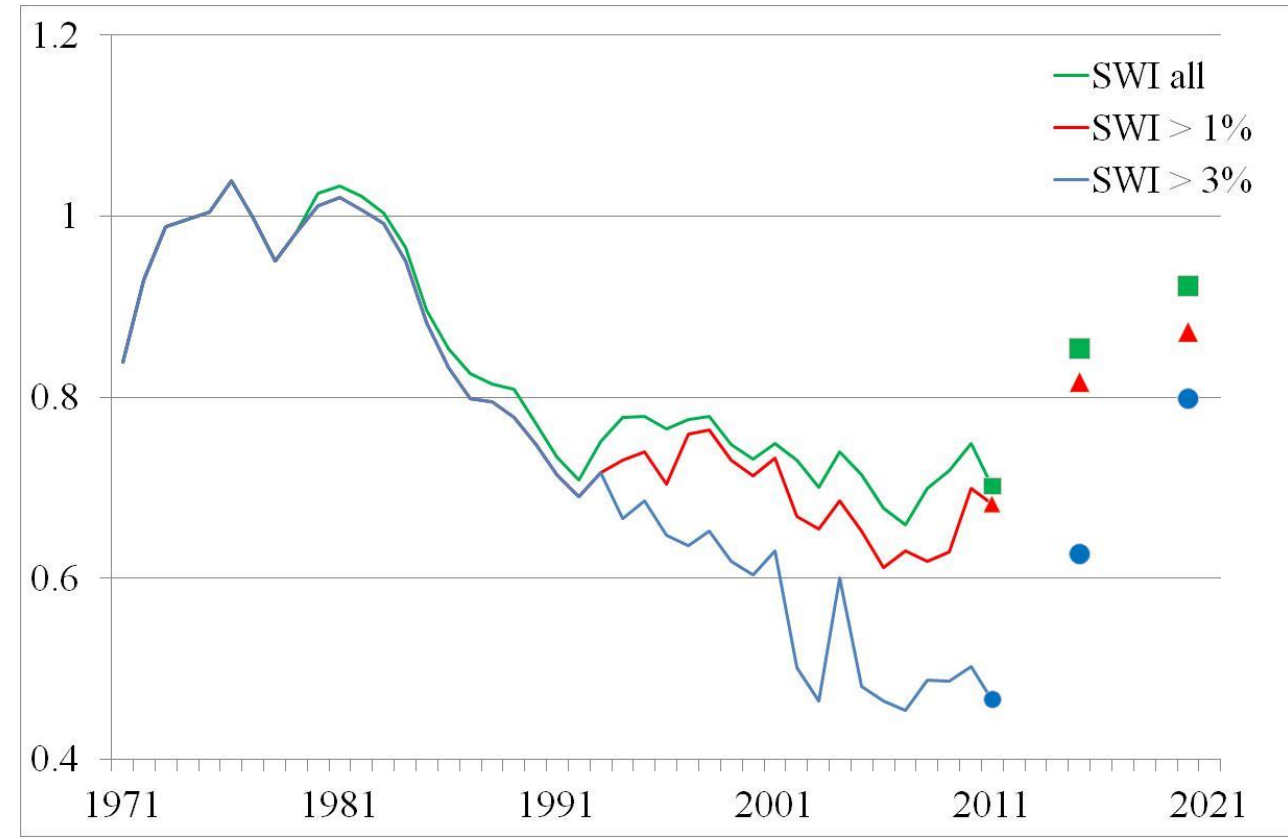

Figure 11: Past and projected SWI

\subsection{Electricity sector decarbonisation}

Electricity sector decarbonisation is often perceived as a threat to energy supply security. That is based on a more traditional paradigm of energy security that puts emphasis on import independence and has been prominent in most countries until recently [89]. As it has been shown, China relied entirely on indigenous energy resources for electricity generation until very recently. It has done so at the expense of supply diversity and at the expense of the environment. Weak climate change policies and pathway dependence in the energy technologies used are the main reasons why China remains in a carbon lock-in trajectory [90]. It does so even though coal has to be imported and therefore does not support the energy security dogma of using indigenous resources. International trade and China's role as the world's main producing country explain partly the constantly increasing emissions [91].

In theory, decarbonisation of the Chinese electricity sector could be assisted by a greater contribution of natural gas that would substitute coal. Since the emissions ratio between natural gas and coal is approximately 2 (subject to technologies used and fuel quality) it is fair to suggest that the potential of this substitution would be highly beneficial [23, 92]. However, demand for natural gas exceeds supply and therefore imports are required. At present China imports natural gas with pipelines from Myanmar [93], Turkmenistan, Uzbekistan and Kazakhstan [94]. There is also a proposed pipeline from the Russian Siberia and there are regular LNG shipments from Qatar, Australia and Malaysia [95]. According to IEA, China has huge unexploited reserves of coalbed methane but less so of conventional natural gas [96].

However, following the ongoing conflict with Ukraine [97] and the subsequent political discourse to end the European reliance on Russian gas led Russia to sign a long-term gas supply agreement with China in 2014 [98]. For China that was an important energy deal 
given the role that natural gas can play in decarbonisation both by substituting coal and by enabling gas turbines to balance the interment renewable energy supply. The US\$400bn deal will supply $38 \mathrm{bn} \mathrm{m}^{3}$ /annum Russian gas to China for 30 years. Despite the fact that this is just $20 \%$ of the gas that Russia exports to Europe, it will allow China valuable time to develop its own gas resources, support further integration of intermittent renewable and substitute coal and even consider investment in large scale compressed air energy storage systems [99].

While progress in the Chinese nuclear sectors is underway, there are fuel supply limitations that need to be considered. However, the role of nuclear energy in improving energy supply security and contributing to a forward looking decarbonisation strategy is heavily contested. In addition to fuel supply uncertainty, the wisdom of decarbonising by investing in carbonintensive infrastructure building is questioned [100]. In spite of this view, emerging economies (more so than other, "established" nuclear countries), appear to internalise in their climate change policies the aggressive development of nuclear energy [101].

\subsection{Pathway dependence and the risks for energy supply security}

Pathway dependence and status quo bias are common in the energy sector and typical of centrally planned economies. Reiche [102] and Chalvatzis [103] suggested that Eastern European countries had to fight against pathway dependencies in order to adapt to the EU's energy and environmental policies. China's main driver however, is not some higher level of political authority even though the global climate change regime often attempts to assume this role. Rapid economic development and endless thirst for energy resources have led China's fuel mix changes.

There is little doubt that the established, vertically integrated, from mining to power generation, coal sector of China acts as an inflexible incumbent in any fuel mix changes ordered by the Government. To this end the emergence of energy policy is typically deliberate only from the incumbent's point of view and does not allow new entrants to form policy [104]. By highlighting the interests of the dominant, incumbent groups the debate about energy security is often focused on encountering short-terms shocks in supply caused by known tractable drivers. Indeed Berkes et al [105], Folke et al [106, 107], Gunderson, and Holling [108], Holling [109] and Stirling [110, 111] find that there is a consistent preference for control-based strategies in governance interventions that mitigate technological vulnerabilities. In Stirling's taxonomy of vulnerability risks [111] this approach ignores the long-term stresses and those vulnerabilities the underlying cause of which is lesser identifiable or tractable.

We find that the pursuit of secure energy supply in China appears to be leading its electricity sector away from the dominance of coal, towards a diversified fuel mix which includes renewable energy sources, natural gas and nuclear energy. At this stage this is only a gradual, incremental change that will not deliver a radically different fuel mix in less than a decade. It does, however, produce noticeable results in diversifying the electricity sector. Unfortunately, this comes at a cost for the sector's import dependence but as we have shown this is partly because of China's self-imposed coal production limits. Overall, the Government appears to 
have the strength to control the development of the fuel mix against the incumbent interests who would dictate a large-scale and long-term coal lock-in.

In resisting to the dominant coal interests the Chinese Government is supported by two more, often overlooked issues. Firstly, is the water-energy nexus; the interrelation of water and energy as crucial components of each other's production. Chinese coal production is water intensive and this imposes productivity restrictions in a number of regions [112]. Conflict around water management is not limited to China's coal production but is a regular issue in exploiting high altitude water resources in the Western Provinces of the country [113] Secondly, the regional disparities in energy and emissions efficiency and the availability of natural and human resources produce a complex environment for energy policy discourse development. As a result, policies do not always manage to prevent regional emission and economic activity leakage which exacerbates imbalances [114] In addition to envisioning economic growth and innovation the Chinese Government is also driven by these two factors.

\section{Conclusion}

China's rapid growth rate presents a challenge as well as an opportunity for the country's energy future. The challenge is to secure increasing energy supplies while maintaining a decarbonisation trajectory. In contrast, the opportunity lies in transforming the historical coal lock-in into a diversified and secure energy supply system that will fuel the Chinese economy for the years to come.

We argue that the Chinese Government is stirring away from the monolithic coal-dominated fuel mix and increases the diversity of the electricity sector. Fuel mix innovation is an effective way of increasing supply security, especially when indigenous coal production cannot cope with demand. It is recommended that the Government continues to work towards two main objectives. First, increase the share of renewable energy sources in the fuel mix and as a result maintain high energy independence. Secondly, improve diversity in the fuel mix; if imports are necessary, prioritise non-coal fuels, such as nuclear fuels and natural gas. These two objectives will improve further electricity supply security while allowing China to decarbonise its economy.

In optimising China's technological substitution, policy makers must design a path that will be influenced by the international energy prices and the role of technological damping caused by China or other countries. In this process climate policy, its effect on energy prices and their subsequent consequences onto the well-being of the global economy will also need to be considered [115]. Our results strengthen those of Wu et al [116] who suggest that controlling emissions and improving energy supply security are not conflicting targets for China.

The success of China's decarbonisation trajectory is keenly observed by the international community. The capacity of the Chinese Government to commit to international emission targets is linked to its capacity to achieve these targets without compromising its energy supply security and development prospects. Further research on this issue should focus on the 
regions of China, their specific energy supply requirements and their capacity to contribute to the Chinese energy demand. The national dependence and diversity assessment provided in this manuscript have to be complemented with regionally assessments in order to detail the most effective and secure decarbonisation policies.

\section{References}

[1] Armaroli N, Balzani V. Towards an electricity-powered world. Energy and Environmental Science 2011; 4(9):3193-3222.

[2] Khatib H. Electricity in the global energy scene. IEE Proceedings Part A: Science, Measurement and Technology 1993; 140(1):24-28.

[3] Balat M. Electricity from worldwide energy sources. Energy Sources Part B: Economics, Planning and Policy 2006;1(4):395-412.

[4] Kalkuhl M, Edenhofer O, Lessmann K. Learning or lock-in: Optimal technology policies to support mitigation. Resource and Energy Economics 2012;34(1):1-23.

[5] Turton, H., Moura, F. Vehicle-to-grid systems for sustainable development: An integrated energy analysis, Technological Forecasting and Social Change 2008; 75 (8), pp. 10911108 .

[6] Shi, Q., Lai, X., Identifying the underpin of green and low carbon technology innovation research: A literature review from 1994 to 2010, Technological Forecasting and Social Change 2013; 80 (5), pp. 839-864.

[7] Blesl M, Kober T, Bruchof D, Kuder R. Effects of climate and energy policy related measures and targets on the future structure of the European energy system in 2020 and beyond. Energy Policy 2010;38(10):6278-6292.

[8] Knapp KE. Exploring energy technology substitution for reducing atmospheric carbon emissions. Energy Journal 1999;20(2):121-143.

[9] Grubb M, Butler L, Twomey P. Diversity and security in UK electricity generation: The influence of low-carbon objectives. Energy Policy 2006;34(18):4050-4062.

[10] Flavin C, Dunn S. A New Energy Paradigm for the 21st Century. Journal of International Affairs 1999;53(1):169-190.

[11] Energy Security in a Multipolar World (ESMW) Research Cluster. Meeting Report: EUUK Energy Security: Perceptions and Realities. <http://www.exeter.ac.uk/energysecurity/documents/ESMW_Meeting_Report-EUUK_Energy_Security.pdf >; 2011.

[12] Nuttall, W.J., Manz, D.L., A new energy security paradigm for the twenty-first century, Technological Forecasting and Social Change, 75 (8), pp. 1247-1259.

[13] Stirling A. Diversity and ignorance in electricity supply investment: Addressing the solution rather than the problem. Energy Policy 1994;22(3):195-216.

[14] Makansi J, Abboud J. Energy Storage: The missing link in the electricity value chain, An Energy Storage Council (ESC) white paper. <http://www.energystoragecouncil.org/ESC\%20White\%20Paper\%20.pdf>; 2002. 
[15] Zafirakis, D., Chalvatzis, K.J., Baiocchi, G., Daskalakis, G., Modeling of financial incentives for investments in energy storage systems that promote the large-scale integration of wind energy, 2013, Applied Energy, 105, pp. 138-154.

[16] Poudineh, R., \& Jamasb, T. (2014). Distributed generation, storage, demand response and energy efficiency as alternatives to grid capacity enhancement. Energy Policy, 67, 222-231.

[17] B. Metz, O.R. Davidson, P.R. Bosch, R. Dave, L.A. Meyer (eds). Contribution of Working Group III to the Fourth Assessment Report of the Intergovernmental Panel on Climate Change. Cambridge University Press, Cambridge, United Kingdom and New York, NY, USA. <http://www.ipcc.ch/publications_and_data/ar4/wg3/en/contents.html>; 2007.

[18] Verbong, G.P.J., Geels, F.W., Exploring sustainability transitions in the electricity sector with socio-technical pathways, 2010, Technological Forecasting and Social Change, 77 (8), pp. 1214-1221.

[19] Kaldellis, J.K., Spyropoulos, G., Chalvatzis, K.J., 2004, “The impact of Greek electricity generation sector on the national air pollution problem", Fresenius Environmental Bulletin 13 (7), 647-656.

[20] Australian Government Productivity Commission; Carbon Emission Policies in Key Economies - Research report; 2011

[21] van den Bergh, J.C.J.M., Environmental and climate innovation: Limitations, policies and prices, 2013, Technological Forecasting and Social Change, 80 (1), pp. 11-23.

[22] Chalvatzis KJ. "Analysis of the evaluation of electricity supply security: Case studies for electricity sector incumbents and policy makers in Greece and Poland", PhD Thesis, School of Environmental Sciences, Faculty of Sciences, University of East Anglia, 2012.

[23] Zha, D., Ding, N., Elasticities of substitution between energy and non-energy inputs in China power sector, 2014, Economic Modelling 38, pp. 564-571

[24] World Bank. Sustainable low-carbon city development in China / edited by Axel Baeumler, Ede Ijjasz-Vasquez, and Shomik Mehndiratta; 2012

[25] Zafirakis, D., Chalvatzis, K., Kaldellis, J.K., 2013, "Socially just" support mechanisms for the promotion of renewable energy sources in Greece", Renewable and Sustainable Energy Reviews 21, 478-493.

[26] Chinese Government. China's Energy 2012, http://english.gov.cn/official/201210/24/content_2250497.htm, 2013.

[27] International Energy Agency, "Medium-term coal market report", 2012. http://www.iea.org/Textbase/npsum/MTCoalMR2012SUM.pdf

[28] Xie Q, Hua M, Wu P. China's uranium industry, "going out” policy: opportunities and challenges (我国铀矿业 “走出去” 所面临的机遇与挑战) China Mining Magazine. 2011; 20(12):16-19

[29] Guidolin, M., Guseo, R., A nuclear power renaissance?, 2012, Technological Forecasting and Social Change, 79 (9), pp. 1746-1760.

[30] Robin W. Grimes and William J. Nuttall, 2010, "Generating the Option of a Two-Stage Nuclear Renaissance”, Science, Vol. 329 no. 5993 pp. 799-803 
[31] International Atomic Energy Agency (IAEA), 2014, "Under Construction Reactors", <http://www.iaea.org/PRIS/WorldStatistics/UnderConstructionReactorsByCountry.aspx $>$

[32] Dalla Valle, A., Furlan, C., 2014, "Diffusion of nuclear energy in some developing countries", Technological Forecasting and Social Change 81 (1), pp. 143-153.

[33] Wüstenhagen, R., Menichetti, E., 2012, "Strategic choices for renewable energy investment: Conceptual framework and opportunities for further research", Energy Policy, 40 (1), pp. 1-10.

[34] Pahle, M., 2010, “Germany's dash for coal: Exploring drivers and factors”, Energy Policy, vol. 38, no 7, pp. 3431-3442.

[35] Goldthau, A., Sovacool, B.K., 2012, “The uniqueness of the energy security, justice, and governance problem", Energy Policy, 41, pp. 232-240.

[36] Van der Vleuten, E., Lagendijk, V., 2010, "Transnational infrastructure vulnerability: The historical shaping of the 2006 European "Blackout"', Energy Policy, vol. 38, no 4, pp. 2042-2052.

[37] The Independent, 2006, "Europe suffers worst blackout for three decades", available online at: http://www.independent.co.uk/news/world/europe/europe-suffers-worstblackout-for-three-decades-423144.html.

[38] National Energy Administration, 2014, http://www.mlr.gov.cn/xwdt/mtsy/qtmt/201401/t20140114_1301115.htm

[39] State Grid Energy Research Institute China, Study on Electricity Demand and Electrification Planning by 2030 in China, 2013, http://www.sgeri.sgcc.com.cn/english/Achievements/Awards/researchreports/12/115024. shtml

[40] US Energy Information Administration, 2014, http://www.eia.gov/countries/analysisbriefs/China/china.pdf

[41] Economy, E. C., The River Runs Black. Ithica: Cornell University Press; 2004.

[42] International Energy Agency. CO2 Emissions from Fuel Combustion: Highlights IEA Statistics 2013.

http://www.iea.org/publications/freepublications/publication/CO2EmissionsFromFuelCo mbustionHighlights2013.pdf

[43] Kaldellis, J.K., Chalvatzis, K.J., Spyropoulos, G.C., 2007, “Transboundary air pollution balance in the new integrated European environment", Environmental Science \& Policy 10 (7-8), 725-733

[44] Ma, C.B., and He, L.N. From state monopoly to renewable portfolio: Restructuring China's electric utility. Energy Policy, (36). pp.1697-1711; 2008.

[45] Kahrl, F., Williams, J., Ding, J.H., Hu, J.F. Challenges to China's transition to a low carbon electricity system. Energy Policy, (39); 2011; pp 4032-4031.

[46] Wei, Y.-M., Liang, Q.-M., Fan, Y., Okada, N., Tsai, H.-T., A scenario analysis of energy requirements and energy intensity for China's rapidly developing society in the year 2020, 2006, Technological Forecasting and Social Change 73 (4), pp. 405-421

[47] China National Renewable Energy Centre. The "12th 5 Year Plan of Energy Development”. Available at <http://en.cnrec.info/policy/2013-01-30-454.html> 2013. 
[48] Zeng Ming, Zhang Kun, Dong Jun, 2013. Overall review of China's wind power industry: Status quo, existing problems and perspective for future development. Renewable and Sustainable Energy Reviews, Volume 24, August 2013, Pages 379-386, ISSN 1364-0321

[49] Wang, F., Yin, H.T., and Li, S.D. China's renewable energy policy: Commitments and Challenges. Energy Policy, (38); 2009; pp.1872-1878.

[50] Deng Shasha. Xinhua Net News. Key targets of China's 12th five-year plan. http://news.xinhuanet.com/english2010/china/2011-03/05/c_13762230.htm; 2011.

[51] China Electricity Council (CEC), 2013. Electricity supply and demand analysis and forecast report: 1st 3 quarters of 2013.

http://www.cec.org.cn/guihuayutongji/gongxufenxi/dianligongxufenxi/2013-1107/111817.html

[52] Energy Information Agency (EIA), 2011. International Energy Statistics: Total Recoverable Coal (Millions Short Tons). <http://www.eia.gov/cfapps/ipdbproject/IEDIndex3.cfm?tid=1\&pid=7\&aid=6>

[53] International Energy Agency, 2014. Statistics - China, People's Republic of (including Hong-Kong): Electricity and Heat.

[54] China Energy Statistical Yearbook, 2001-2010. Section 5-1: Energy Balance of China (Physical Quantities). China Statistics Press. ISBN-10: 7503764597.

[55] International Atomic Energy Authority (IAEA), Power Reactor Information System (PRIS), http://www.iaea.org/pris/CountryStatistics/CountryDetails.aspx?current=CN

[56] United States Energy Information Administration, Country Information: China, http://www.eia.gov/countries/cab.cfm?fips $=\mathrm{CH}$

[57] Kahrl, F., Williams, J., Jianhua, D., Junfeng, H., Challenges to China's transition to a low carbon electricity system, 2011, Energy Policy 39 (7), pp. 4032-4041.

[58] Tu, Kevin and Johnson-Reiser, Sabine, 2012. Understanding China’s Rising Coal Imports. Carnegie Endowment for International Peace: Policy Outlook., http://carnegieendowment.org/files/china_coal.pdf

[59] Xinhua net, 2012, China targets annual coal production capacity of 4.1 bln tonnes by 2015, available online at: http://news.xinhuanet.com/english/china/201203/22/c_131483521.htm

[60] International Energy Agency (IEA). World Energy Outlook 2009. OECD/IEA, Paris; 2009.

[61] Leung, Guy C.K., China’s Energy Security: Perception and Reality. Energy Policy, 2011; 39: 1330-1337.

[62] Cao, Wensheng and Bluth, Christoph, Challenges and Counter-Measures of China's Energy Security. Energy Policy, 2013; 53: 381-388.

[63] Zhang, Zhongxiang, China's Energy Security, the Malacca Dilemma and Responses. Energy Policy, 2011; 39: 7612-7615

[64] Winzer, C., 2011, “Conceptualizing energy security”, Energy Policy, vol. 46, pp. 36-48.

[65] Hughes, L., 2012, “A generic framework for the description and analysis of energy security in an energy system”, Energy Policy, vol. 42, pp. 221-231.

[66] Sovacool, B. K., Mukheree, I., 2011, Conceptualizing and measuring energy security: A synthesized approach, Energy, vol. 36, pp. 5343-5355. 
[67] Martchamadol, J., Kumar, S., 2012, “Thailand's energy security indicators”, Renewable and Sustainable Energy Reviews, vol. 16, pp. 6103-6122.

[68] Sovacool, B. K., 2013a, "An international assessment of energy security performance", Ecological Economics, vol. 88, pp. 148-158.

[69] Sovacool, B. K., 2013b, “Assessing energy security performance in the Asia Pacific, 1990-2010, Renewable and Sustainable Energy Reviews, vol. 17, pp. 228-247.

[70] Chuang, M. C., Ma, H. W., 2013, “An assessment of Taiwan's energy policy using multi-dimensional energy security indicators", Renewable and Sustainable Energy Reviews, vol. 37, pp. 301-311.

[71] IEA, 2007a, "Energy Security and Climate Policy: Assessing Interactions", International Energy Agency, OECD, Paris (March), http://www.iea.org/textbase/nppdf/free/2007/energy_security_climate_policy.pdf.

[72] IEA, 2007b, “World Energy Outlook 2007”, International Energy Agency, OECD, Paris, http://www.iea.org/Textbase/npsum/EnergySecurity2007SUM.pdf.

[73] Frondel M., and Schmidt C.M., (2008), Measuring energy security: A conceptual note, Ruhr Economic paper No 52, http://papers.ssrn.com/sol3/Delivery.cfm/SSRN_ID1161141_code343237.pdf?abstractid $=1161141 \&$ mirid $=1$

[74] Chalvatzis K.J. and Hooper E.A. (2009), Energy security vs. climate change: Theoretical framework development and experience in selected EU electricity markets, Renewable \& Sustainable Energy Reviews, 13 (9). pp. 2703-2709.

[75] Cohen, G., Joutz, F., Loungani, P., 2011, "Measuring energy security: trends in the diversification of oil and natural gas supplies", Energy Policy, vol. 39, pp. 4860-4869.

[76] Le Coq, C., Paltseva, E., 2009, "Measuring the security of external energy supply in the European Union", Energy Policy, vol. 37, pp. 4474-4481

[77] Hickey, E.A., Lon Carlson, J., Loomis, D., 2010, "Issues in the determination of the optimal portfolio of electricity supply options", Energy Policy, vol. 38, no. 5, pp. 2198 2207.

[78] Jansne, J. C., Seebregts, A. J., 2010, "Long-term energy services security: What is it and how can it be measured and valued?", Energy Policy, vol. 38, pp. 1654-1664.

[79] Jun, E., Kim, W., Chang, S.H., 2009, "The analysis of security cost for different energy sources”, Applied Energy, vol. 86, no. 10, pp. 1894-1901.

[80] Ferreira, H.L., Costescu, A., L'Abbate, A., Minnebo, P., Fulli, G., 2011, "Distributed generation and distribution market diversity in Europe”, Energy Policy, vol. 39, no. 9, pp. 5561-5571.

[81] United States Department of Justice, 2013, "Herfindahl-Hirschman Index", http://www.justice.gov/atr/public/guidelines/hhi.html

[82] China Daily, 2012, "Nation plans to import more Uranium", http://www.chinadaily.com.cn/cndy/2012-03/13/content_14818316.htm

[83] China Daily, 2012, "Uranium imports to stay on track", http://www.chinadaily.com.cn/business/2012-11/06/content_15879133.htm

[84] Bloomberg, 2010, "Uranium Bottoming as China Buys Supplies From Cameco", http://www.bloomberg.com/news/2010-07-11/uranium-bottoming-as-china-boostsstockpiles-with-10-000-tons-from-cameco.html 
[85] Reuters, 2013, "China struggles to secure uranium supplies after plant halted", http://www.reuters.com/article/2013/07/16/us-china-nuclear-uraniumidUSBRE96F17D20130716

[86] Bloomberg, 2013, "China Oil Stockpiles Climb to Three-Month High as Refining Slows", http://www.bloomberg.com/news/2013-05-22/china-oil-stockpiles-climb-tothree-month-high-as-refining-slows.html

[87] China Daily, 2011, "Natural Gas Stockpiles Crucial to Energy Security", http://usa.chinadaily.com.cn/epaper/2011-02/23/content_12064389.htm

[88] Xinhua, 2012, "Coal stockpiles rise as economy dips", http://news.xinhuanet.com/english/china/2012-06/16/c_131657602.htm

[89] Valentine, S. V. (2011). Emerging symbiosis: Renewable energy and energy security. Renewable and Sustainable Energy Reviews, 15(9), 4572-4578.

[90] Bertram, C., Johnson, N., Luderer, G., Riahi, K., Isaac, M., Eom, J., 2013, "Carbon lockin through capital stock inertia associated with weak near-term climate policies", Technological Forecasting and Social Change, Article in Press.

[91] Minx, J.C., Baiocchi, G., Peters, G.P., Weber, C.L., Guan, D., Hubacek, K., 2011, "Document A "carbonizing Dragon": China's fast growing CO 2 emissions revisited", Environmental Science and Technology, 45 (21), pp. 9144-9153.

[92] Aguilera, R.F., Aguilera, R., 2012, "World natural gas endowment as a bridge towards zero carbon emissions", Technological Forecasting and Social Change 79 (3), pp. 579586.

[93] Financial Times, 2013, "China starts importing natural gas from Myanmar", http://www.ft.com/cms/s/0/870f632c-f83e-11e2-92f000144feabdc0.html\#axzz2pnpuE4Cd

[94] Platts, 2013, "China's Oct gas pipeline imports rise $27 \%$ on year to $2.53 \mathrm{bn} \mathrm{m}$ ", http://www.platts.com/latest-news/natural-gas/singapore/chinas-oct-gas-pipelineimports-rise-27-on-year-2766556

[95] Wall Street Journal, 2013, "China Prepares to Open Its First Deep-Water Gas Project", http://online.wsj.com/news/interactive/CHINAGAS1115?ref=SB1000142405270230467 2404579180991007342138

[96] International Energy Agency (IEA), 2009, "Natural Gas in China Market evolution and Strategy", http://www.iea.org/publications/freepublications/publication/nat_gas_china.pdf

[97] BBC, 2014, "Ukraine crisis: Putin signs Russia-Crimea treaty" http://www.bbc.co.uk/news/world-europe-26630062

[98] Bloomberg, 2014, "Russia, China Sign \$400 Billion Gas Deal After Decade of Talks", available online at: http://www.bloomberg.com/news/2014-05-21/russia-signs-china-gasdeal-after-decade-of-talks.html

[99] Zafirakis, D., Chalvatzis, K.J., 2014, "Wind energy and natural gas-based energy storage to promote energy security and lower emissions in island regions", Fuel 115, 203-219.

[100] Sovacool, B.K., Cooper, C., 2008, "Nuclear nonsense: Why nuclear power is no answer to climate change and the world's post-Kyoto energy challenges", William \& Mary Environmental Law and Policy Review, Vol 33(1), article 2. 
[101] Sovacool, B.K., Valentine, S.V., 2010, “The socio-political economy of nuclear energy in China and India", Energy, 35 (9), pp. 3803-3813.

[102] Reiche, D., 2006, "Renewable energies in the EU-Accession States”, Energy Policy, vol. 34, no. 3, pp. 365-375.

[103] Chalvatzis, K.J., 2009, "Electricity generation development of Eastern Europe: A carbon technology management case study for Poland", Renewable and Sustainable Energy Reviews 13 (6-7), 1606-1612.

[104] Stirling, A., 2008, "Opening up and Closing down: Power, participation, and pluralism in the social appraisal of technology", Science Technology \& Human Values, vol. 33, no. 2, pp. 262-294.

[105] Berkes, F., Colding, J., \& Folke, C., 2003, "Navigating social-ecological systems: building resilience for complexity and change". Cambridge and New York: Cambridge University Press.

[106] Folke, C., Carpenter, S., Walker, B., Scheffer, M., Elmqvist, T., Gunderson, L., 2004, "Regime shifts, resilience, and biodiversity in ecosystem management". Annual Review of Ecology Evolution and Systematics, vol. 35, pp. 557-581.

[107] Folke, C., Hahn, T., Olsson, P., \& Norberg, J., 2005, “Adaptive governance of socialecological systems". Annual Review of Environment and Resources, vol. 30, pp. 441473.

[108] Gunderson, L. H., \& Holling, C. S., 2001, "Panarchy: understanding transformations in human and natural systems". Washington: Island Press.

[109] Holling, C.S., 1978, “Adaptive environmental assessment and management". Chichester and New York: International Institute for Applied Systems Analysis and Wiley.

[110] Stirling A., 2009, “The Dynamics of Security: stability, durability, resilience, robustness", presentation to workshop on 'Energy Security in a Multipolar World', Royal Society, London.

[111] Stirling A., 2012, "From Sustainability, through Diversity to Transformation: Towards More Reflexive Governance of Vulnerability": Chapter in A. Hommels, J. Mesman, and W. Bijker, eds., Vulnerability in Technological Cultures: New Directions in Research and Governance Cambridge MA: MIT Press, forthcoming.

[112] Feng, K., Li, X., Siu, Y.L., Hubacek, K., (2014), “The Energy and Water Nexus in Chinese Electricity Production: A Hybrid Life Cycle Analysis”, Renewable and Sustainable Energy Review 39, 342-355.

[113] Sovacool, B.K., Dhakal, S., Gippner, O., Bambawale, M.J., 2011, "Halting hydro: a review of the socio-technical barriers to hydroelectric power plants in Nepal”, Energy, 36 (5), pp. 3468-3476.

[114] Hubacek, K., Feng, K. (2014), "Efficiency targets fall short of achieving a low carbon future in China", Carbon Management, In Press.

[115] Mercure, J. F., \& Salas, P. (2013). On the global economic potentials and marginal costs of non-renewable resources and the price of energy commodities. Energy Policy, 63, 469-483.

[116] Wu, G., Liu, L. C., Han, Z. Y., \& Wei, Y. M. (2012). Climate protection and China's energy security: Win-win or tradeoff. Applied Energy, 97, 157-163. 


\section{Acknowledgements}

The authors of this paper are grateful to the seminar members of Tyndall Centre for Climate Change Research for the comments provided during the paper's presentation in February 2014. All errors remain a responsibility of the authors.

\section{Biographies}

Dr Konstantinos J. Chalvatzis is a Lecturer in Business and Climate Change at Norwich Business School and at the Tyndall Centre for Climate Change Research. He has visiting appointments at the Department of Geographical Sciences at the University of Maryland, College Park and at the Department of Mechanical Engineering at the Technological Education Institute of Piraeus. His research focus is on technological transitions and futures in the energy sector and the role of innovation in systematic resilience.

Mr Keagan Rubel (Wong Center for MNC) is Managing Partner for Econergy Corporation (HK) Limited, and Senior Director (SE Asia) for Shanghai Sunkai New Energy Technologies. He also serves as senior consultant for epi Consulting and has seven years experience working with Fortune 500 companies and SMEs on sustainability and CSR issues. Mr. Rubel earned his MBA (with Distinction) from the University of East Anglia. He teaches part-time on global sustainability solutions at Hult International Business School and Tongji University (Shanghai). He currently is working on a book on global resource management. 